[Original]

\title{
Physical Training Augments Plasma Catecholamines and Natural Killer Cell Activity
}

\author{
Kazuo TAKAHARA ${ }^{1}$, Yasushi MiUra ${ }^{2}$, Ryouji KouZUMA ${ }^{2}$, \\ Tomiya YASUMASU ${ }^{1}$, Tadashi NAKAMURA ${ }^{2}$ and Yasuhide NAKASHIMA ${ }^{2}$ \\ ${ }^{1}$ The Department of Medical Technology I, School of Health Sciences, \\ ${ }^{2}$ The Second Department of Internal Medicine, School of Medicine, \\ University of Occupational and Environmental Health, Japan. \\ Yahatanishi-ku, Kitakyushu 807-8555, Japan
}

Abstract: To elucidate the effects of a 10 -week exercise training period on physical fitness and plasma catecholamine concentration at rest, and on natural killer cell activity in young healthy untrained females, subjects $(20-22$ years old. $\mathrm{N}=16)$ carried out physical training by a protocol which consisted of treadmill jogging at a workintensity of $50 \%$ of their $\dot{\mathrm{V}}{ }_{2 m a x}$, two hours a day three times a week for ten weeks. $\quad \dot{\mathrm{V}}{ }_{2 \max }$ was increased significantly from $33.1 \pm 3.4 \mathrm{ml} / \mathrm{kg} / \mathrm{min}$ to $38.3 \pm$ $6.6 \mathrm{ml} / \mathrm{kg} / \mathrm{min}$ by the ten weeks of physical training $(P<0.005)$, and natural killer cell activity was also increased significantly from $31.9 \pm 14.3 \%$ to $46.4 \pm 18.4$ $\% \quad(P<0.05)$. The concentrations of epinephrine and norepinephrine before and after physical training were $18.3 \pm 8.7 \mathrm{pg} / \mathrm{ml}$ and $20.4 \pm 8.9 \mathrm{pg} / \mathrm{ml}$, and 134.1 $\pm 52.2 \mathrm{pg} / \mathrm{ml}$ and $248.1 \pm 106.8 \mathrm{pg} / \mathrm{ml}(P<0.005)$, respectively. Changes in norepinephrine and epinephrine correlated with the change in $\dot{\mathrm{VO}}_{2 \max }(\mathrm{r}=0.780$, $P<0.005 ; \mathrm{r}=0.556, P<0.05)$. While the change in natural killer cell activity correlated with the change in epinephrine $(r=0.623, P<0.01)$, the correlation of the change in natural killer cell activity with change in norepinephrine did not reach statistical significance $(\mathrm{r}=0.497, P=0.0503)$. From these results we concluded that physical training augments plasma catecholamine levels and natural killer cell activity at rest in young healthy females.

Key words:physical training, catecholamine, natural killer cell, fitness, oxygen uptake.

(Received 14 June 1999, accepted 8 October 1999)

\section{Introduction}

A substantial number of reports suggest that regular physical activity is associated with a reduced risk of coronary heart disease $[1-7]$ and all-cause mortality including cancer [69]. The mechanism by which this protection occurs appears in part to be related to de- 
creased blood pressure, lower body mass, higher high-density lipoprotein (HDL) cholesterol, lower total cholesterol/HDL ratio, and a lower prevalence of smoking associated with physical activity $[10-12]$.

Regarding the effects of physical training on the catecholamine concentration, some earlier studies reported that catecholamine concentration was lower at rest in trained than in untrained subjects [13], and in response to given exercise loads, catecholamine concentrations are generally found to increase less in trained than in untrained subjects $[14,15]$. But recently some studies have reported that plasma catecholamine levels were not reduced at rest in trained compared with untrained subjects [14-16], and Dela et al . reported that epinephrine levels were higher in trained than in untrained subjects during sleep [17].

Natural killer cells are considered to play an important role in the first line of defense against viral infection and the spread of malignant disease $[18,19]$. Natural killer cells are defined as major histocompatibility complex independent cytotoxic lymphocytes that do not express the cluster designation 3 cell-surface antigen. Their concentration and activity are influenced by physical stressors, including surgery [20], burns [21], acute myocardial infarction [22], hypovolemia [23], and hyperthermia [24]. Furthermore, natural killer cells are recruited to blood during exercise [25], but it is not clear whether physical training affects the natural killer cells activity or not.

The aim of the present study was to elucidate the effects of a 10-week exercise training period on physical fitness and plasma catecholamine concentration at rest, and on natural killer cell activity as an immune response parameter.

\section{Subjects and Methods}

The subjects for this study were 16 females aged from 20 to 22 years old. They were healthy and relatively sedentary students who were not in the habit of taking regular exercise. None of the subjects smoked or were taking medication, and none were in the midst of menstruation on the sampling day. Written informed consent was obtained from each subject before the study.

To measure the physical fitness, each subject performed a graded treadmill run to exhaustion according to the Bruce protocol [26]. We analyzed the expiratory gas with a gas analyzer (Aerometer : AE-280 Minato Medical Science Co., Ltd. , Osaka, Japan) with a turbine transducer. The breath by breath data were averaged for $15 \mathrm{sec}$ throughout the exercise test. When the heart rate did not reach more than $90 \%$ of the predicted maximal heart rate $(220$-age $)$ or when the ratio of expired $\mathrm{CO}_{2}$ and inspired $\mathrm{O}_{2}$ did not exceed 1.1, we did not employ the peak value of the oxygen uptake as a maximal oxygen uptake $\left(\dot{\mathrm{V}} \mathrm{O}_{2 \max }\right)$. According to these criteria, no tests were excluded.

The physical training protocol involved treadmill jogging at $50 \% \dot{\mathrm{V}} \mathrm{O}_{2 \max }$ intensity for two hours a day three times a week over a period of 10 weeks. $50 \% \dot{\mathrm{VO}}_{2 \max }$ was set by the 
heart rate determined $\dot{\mathrm{V}} \mathrm{O}_{2 \mathrm{max}}$ was previously measured.

After fasting overnight, $10 \mathrm{ml}$ of blood was obtained by venipuncture after $30 \mathrm{~min}$ bed rest at a room temperature of $23^{\circ} \mathrm{C}$. Five $\mathrm{ml}$ of blood was kept at $4^{\circ} \mathrm{C}$ with a $0.7 \mathrm{ml}$ of CPD buffer (sodium citrate $2.63 \mathrm{~g}$, citrate $0.327 \mathrm{~g}$, glucose $2.32 \mathrm{~g} / 100 \mathrm{ml}$ ) to measure natural killer cell activity by ${ }^{51} \mathrm{Cr}$ releasing assay [27]. After centrifugation of the remaining blood at $1000 \mathrm{~g}$ for $15 \mathrm{~min}$, the plasma was frozen at $-20^{\circ} \mathrm{C}$ until assayed. Plasma epinephrine and norepinephrine were measured by high performance liquid chromatography before and after the 10 -week physical training period. To determine cholesterol levels, another $10 \mathrm{ml}$ of blood samples were collected in tubes containing ethylenediaminetetraacetate. Cholesterol, triglyceride content in the plasma and LDL and HDL cholesterol levels were measured enzymatically.

\section{Statistics}

All data are expressed as mean \pm standard deviation. Paired $t$ test for paired observations was employed whenever appropriate. Simple linear regression was performed when correlation was considered. Differences were considered statistically significant at $P$ values $<$ 0.05 .

\section{Results}

Physical characteristics of all subjects are shown in Table 1 . The average body weight was $47.5 \pm 3.6 \mathrm{~kg}$, and their body weight after ten weeks was $47.7 \pm 3.6 \mathrm{~kg}$, so body weight did not change significantly in this study. Table 2 shows the total cholesterol, low-density lipoprotein (LDL) cholesterol, HDL cholesterol and triglyceride concentrations of the subjects. The physical training did not result in any obvious changes, however the $\dot{\mathrm{V}} \mathrm{O}_{2 \text { max }}$ rose significantly from $33.1 \pm 3.4 \mathrm{ml} / \mathrm{kg} / \mathrm{min}$ to $38.3 \pm 6.6 \mathrm{ml} / \mathrm{kg} / \mathrm{min} \quad(P<0.005$, Fig. 1 ). Physical training augmented plasma norepinephrine at rest significantly $(248.1 \pm 106.8 \mathrm{pg} / \mathrm{ml}$ vs $134.1 \pm$ $52.2 \mathrm{pg} / \mathrm{ml} ; P<0.005$, Fig. 2 .), but epinephrine did not show any clear statistical change $(20.4 \pm 8.9 \mathrm{pg} / \mathrm{ml}$ vs $18.3 \pm 8.7 \mathrm{pg} / \mathrm{ml})$. On the other hand, natural killer cells activity increased significantly from $31.9 \pm 14.3 \%$ to $46.4 \pm 18.4 \% \quad(P<0.05$, Fig. 3$)$. In three persons, $\dot{\mathrm{VO}}_{2 \max }$ deteriorated and their epinephrine levels also decreased after 10 weeks of physical training, and norepinephrine levels decreased in one of these three subjects.

The change in norepinephrine was calculated as the difference in concentration of norepinephrine before and after physical training, and change in epinephrine correlated with change in $\dot{\mathrm{VO}}_{2 \max }(\mathrm{r}=0.780, P<0.005$, Fig. 4 .; and $\mathrm{r}=0.556, P<0.05$, Fig. 5$)$. The change in natural killer cell activity correlated with change in epinephrine $(\mathrm{r}=0.623, P<$ 0.01 , Fig. 6 ). In general, subjects whose $\dot{\mathrm{V}}_{2 \max }$ increased greatly also showed large increases in catecholamine levels and natural killer cell activity, but the correlation of natural 
killer cell activity with norepinephrine did not reach statistical significance $(\mathrm{r}=0.497, P=$ 0.0503).

Table 1. Physical Characteristics of Subjects

\begin{tabular}{lc}
\hline Body height $(\mathrm{m})$ & $1.57 \pm 0.036$ \\
Body weight $(\mathrm{kg})$ & $47.5 \pm 3.6$ \\
BMI $\left(\mathrm{kg} / \mathrm{m}^{2}\right)$ & $19.3 \pm 1.7$ \\
Systolic blood pressure $(\mathrm{mmHg})$ & $99.8 \pm 8.8$ \\
Heart rate $(\mathrm{bpm})$ & $66.8 \pm 10.9$ \\
\hline
\end{tabular}

BMI ; body mass index, bpm ; beats per minute.

Table 2. Plasma Lipids before and after Physical Training

\begin{tabular}{lrrr}
\hline & \multicolumn{1}{c}{ before PT } & \multicolumn{1}{c}{ after PT } \\
\hline T-cho. $(\mathrm{mg} / \mathrm{dl})$ & $172.6 \pm 40.9$ & $174.8 \pm 35.3$ \\
LDL-cho. $(\mathrm{mg} / \mathrm{dl})$ & $93.1 \pm 28.5$ & $93.0 \pm 29.1$ \\
HDL-cho. $(\mathrm{mg} / \mathrm{dl})$ & $56.2 \pm 17.0$ & $59.5 \pm 18.6$ \\
TG. $\quad(\mathrm{mg} / \mathrm{dl})$ & $71.1 \pm 30.7$ & $76.1 \pm 22.9$ \\
\hline
\end{tabular}

cho. ; cholesterol, PT ; physical training, T ; toral, TG ; triglyceride.

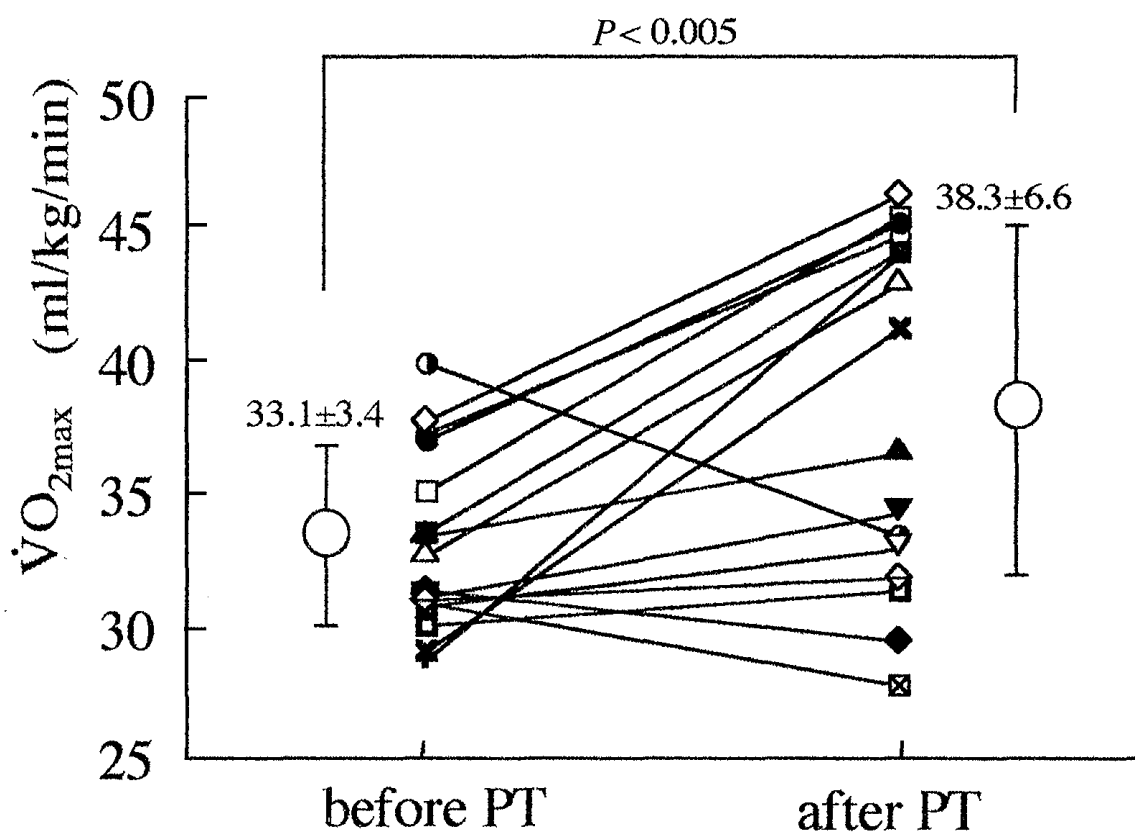

Fig. 1. $\dot{\mathrm{V}} 2 \max$ before and after physical training.

$\dot{\mathrm{V}}{ }_{2 m a x}$ levels were augmented significantly in all but three subjects, whose $\dot{\mathrm{V}} 2$ max deteriorated after physical training. Error bar shows the standard deviation. PT ; physical training, $\dot{\mathrm{V}} 2 \max$; maximal oxygen uptake. 


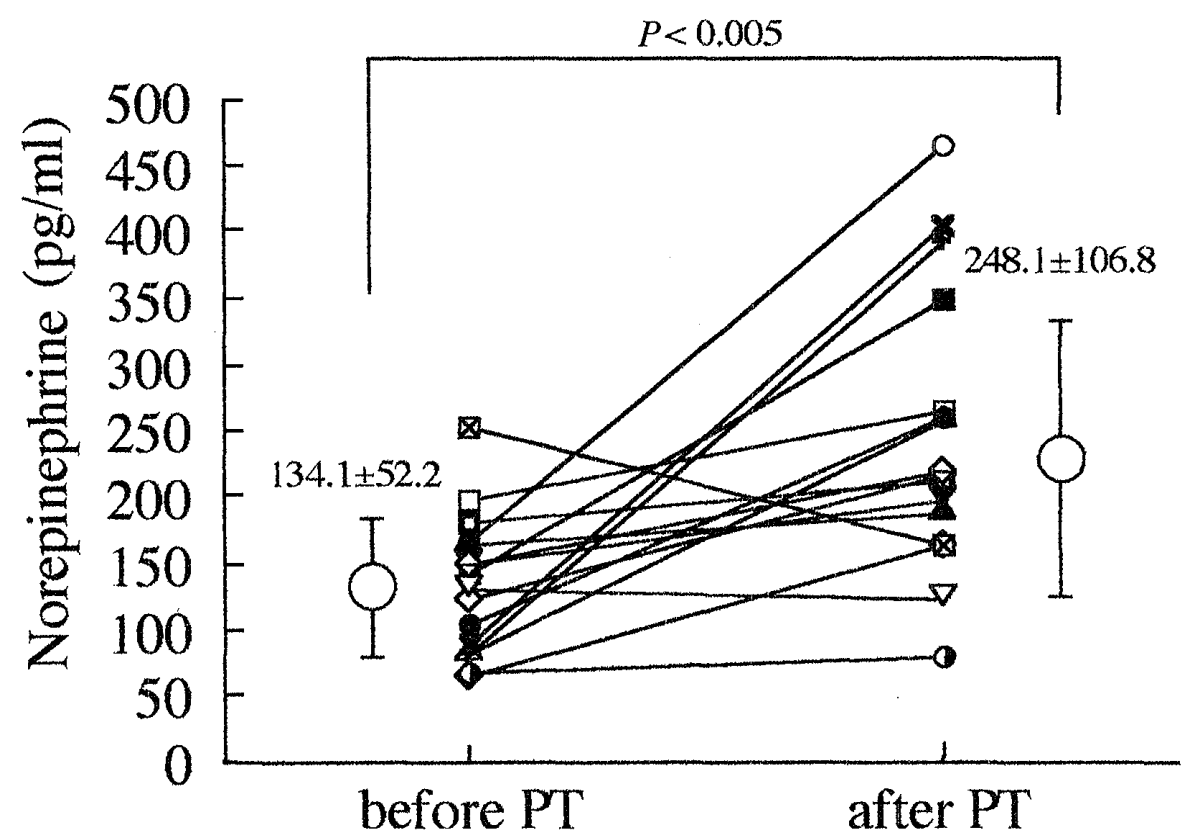

Fig. 2. Plasma norepinephrine concentrations before and after physical training.

Plasma norepinephrine concentrations were augmented by physical training. Error bar shows standard deviation.

PT ; physical training.

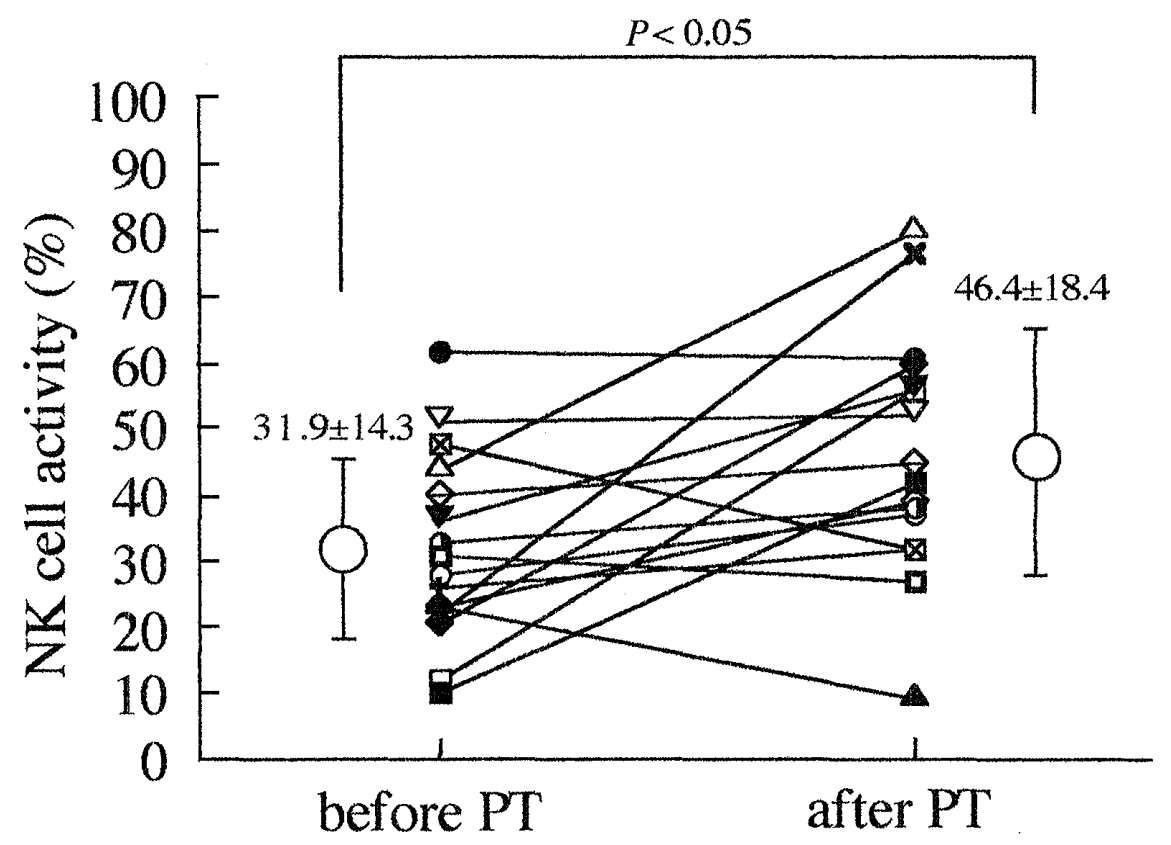

Fig. 3. Natural killer cell activity before and after physical training. Natural killer cell activity was augmented significantly. Error bar shows standard deviation. 


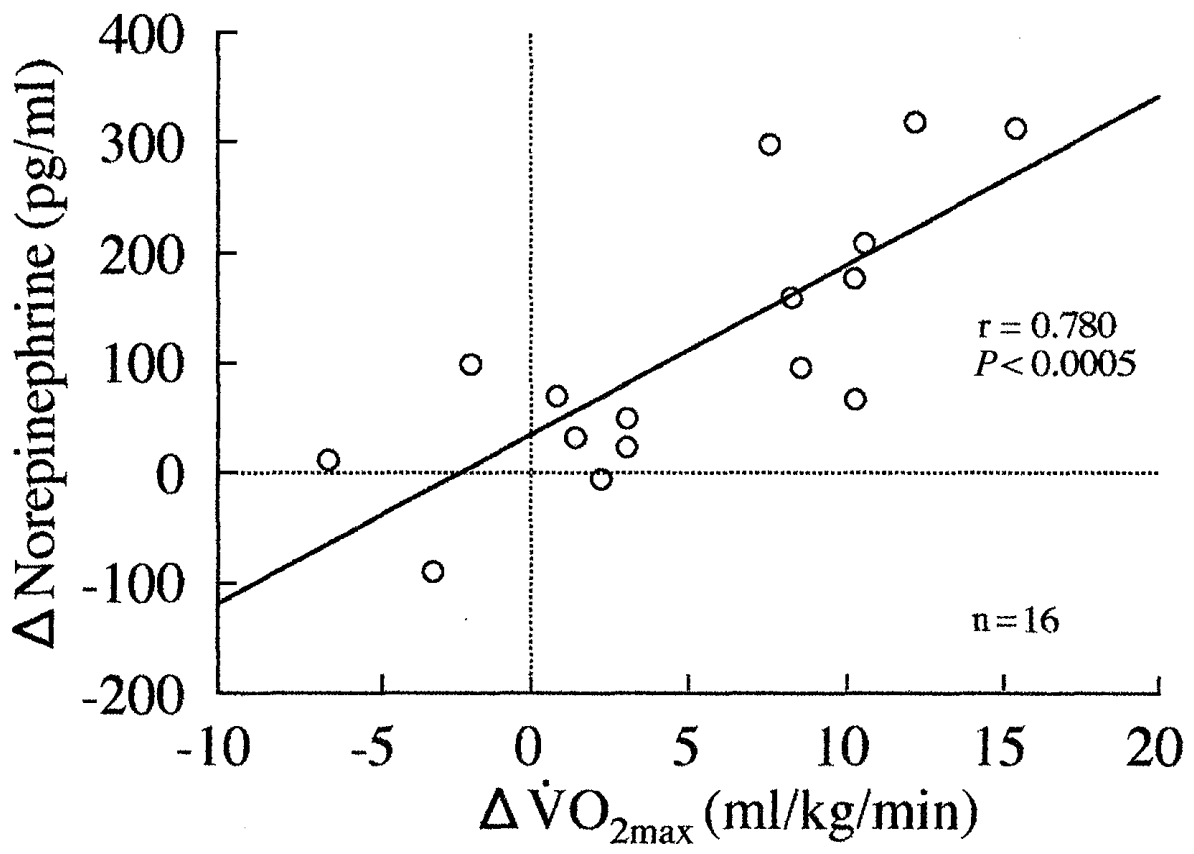

Fig. 4. Correlation between change in $\dot{\mathrm{V}} \mathrm{O}_{2} \max$ and change in norepinephrine.

$\Delta$ norepinephrine correlated with $\Delta \dot{\mathrm{V}}_{2 \max }$ significantly $(\mathrm{r}=0.780, P<0.005)$.

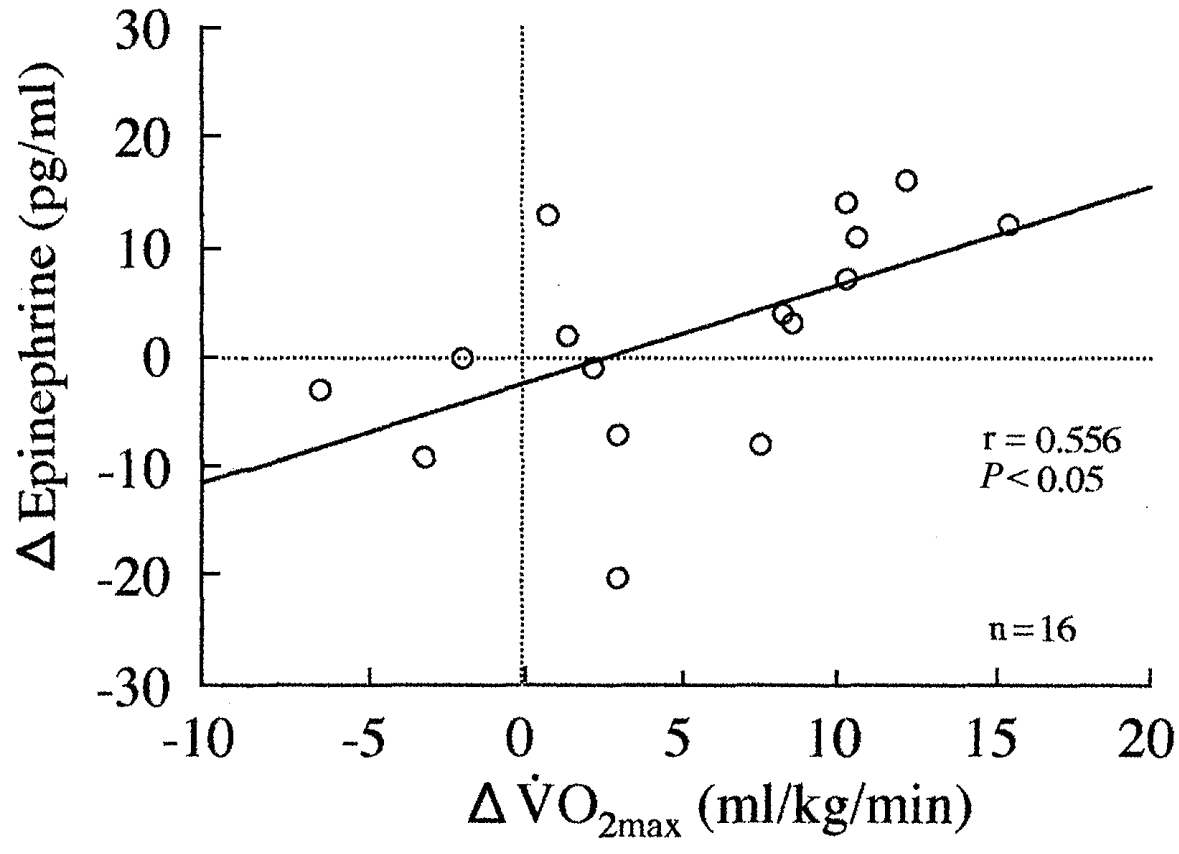

Fig. 5. Correlation between change in $\mathrm{VO}_{2} \max$ and change in epinephrine.

$\Delta$ epinephrine correlated with $\Delta \dot{\mathrm{V} O} 2 \max$ significantly $(\mathrm{r}=0.556, P<0.05)$. 


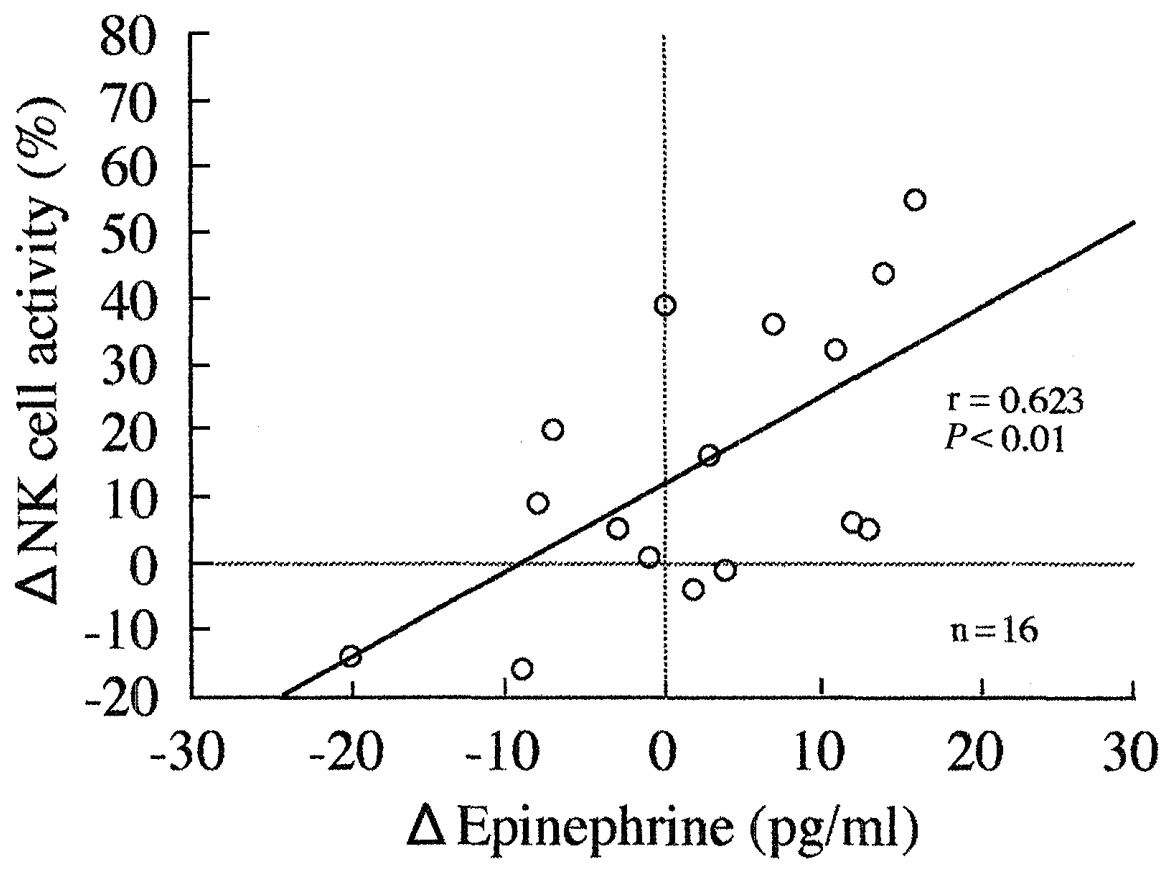

Fig. 6. Correlation between change in epinephrine and change in natural killer cell activity.

$\Delta$ natural killer cell activity correlated with $\Delta$ epinephrine significantly $(r=0.623, P<0.01)$, but the correlation with $\Delta$ norepinephrine did not reach statistical significance $(\mathrm{r}=0.497, P=0.0503)$.

\section{Discussion}

The present study shows that periodical physical training augments plasma norepinephrine and natural killer cell activity at rest (Fig. 1,2,3). It has been well documented in previous studies that for a given sub-maximal workload both plasma norepinephrine and epinephrine are reduced in endurance-trained rats compared with their sedentary counterparts $[28,29]$. In humans, however, it is controversial whether plasma catecholamine levels will be reduced at rest in trained compared with untrained subjects $[13-16]$. In contrast to some earlier studies using fluorometric catecholamine assays $[13,14]$, but in agreement with studies using more precise radioenzymatic assays [14-16] or with microneurography, plasma catecholamine levels were not reduced at rest in trained compared with untrained subjects. Such differences in opinion may be the result of differences in the degree of physical fitness of the subjects. Dela et al . reported that epinephrine levels were higher in trained than in untrained subjects during sleep [17]. In our study, the physical training increased their physical fitness significantly, and this was accompanied by an increased plasma catecholamine level at rest. Furthermore changes in norepinephrine and epinephrine concentrations correlated with change in $\dot{\mathrm{VO}}_{2 \text { max. }}$. This means that plasma catecholamine levels are higher in trained states than in untrained states in the same subjects, at least in young females. In 
general, periodical physical training brings an increase of $\dot{\mathrm{VO}}_{2 \mathrm{max}}$, and the degree of the rise of $\dot{\mathrm{VO}}_{2 \max }$ shows a positive correlation with load strength. Therefore, in the subjects whose $\dot{\mathrm{VO}}_{2 \text { max }}$ did not increase after physical training, it is suspected that their physical training was insufficient. The change in $\dot{\mathrm{V}} \mathrm{O}_{2 \max }$ shows a positive significant correlation with plasma catecholamine and natural killer cell activity (Fig. 4,5 and 6). Using a spectral analysis of $\mathrm{RR}$ interval variability on an electrocardiogram, Furlan et al. reported that heavy dynamic exercise produces long lasting sympathetic activation in healthy subjects [30]. However, their results might be influenced by the time after the cessation of exercise. We took the blood samples in the morning after 30 min bed rest, so we concluded that physical training may augment plasma catecholamine at rest.

Natural killer cell activity has been reported to increase after a single exercise session $[31,32]$, and also has been reported recently after moderate exercise training by Nieman et al. [33]. Our study suggests that natural killer cell activity also increases after physical training. But in an in vivo study like this, the condition of the subjects before and after physical training is not always the same, for example, seasonal changes might affect the natural killer cell activity. We therefore can not exclude these limitations at this time.

Kappel et al. reported that intravenous administration of epinephrine resulting in plasma levels similar to those obtained during cycling recruits natural killer cells to blood, and that natural killer cell activity is mediated by epinephrine [34]. Therefore it is reasonable that the increased levels of plasma catecholamines at rest may also augment the natural killer cell activity by recruiting natural killer cells to blood. Our finding that change in catecholamine correlated with change in natural killer cell activity is supported by Kappel's findings which showed acute effects of catecholamine. Our findings of increasing natural killer cell activity after a 10 -week exercise period are also in agreement with the report by Nieman et al. after 15-week exercise [33]. Regular physical activity is reported to be associated with a reduced risk of all-cause mortality including cancer [6-9] and natural killer cells are considered to play an important role in preventing the spread of malignant disease $[18,19]$. In our study physical training increased natural killer cell activity, and this may be one reason for the reduced risk of all-cause mortality, including cancer, but this remains to be established.

\section{References}

1. Kannel WB, Belanger A, D’ Agostino R \& Israel I (1986) : Physical activity and physical demand on the job and risk of cardiovascular disease and death : The Framingham Study. Am Heart J 112 : $820-825$

2. Leon AS \& Connett J (1991) : Physical activity and 10.5 year mortality in the Multiple Risk Factor Intervention Trial（MRFIT). Int J Epidemiol 20: 690-697

3. Morris JN, Clayton DG, Everitt MG, Semmence AM \& Burgess EH (1990) : Exercise in leisure 
time : coronary attack and death rate. Br Heart J $63: 325-334$

4. Paffenbarger RS, Hyde RT, Wing AL \& Hsieh CC (1986) : Physical activity, all-cause mortality, and longevity of college alumni. N Engl J Med 314 : 605-613

5 . Shaper AG \& Wannamethee G (1991) : Physical activity and ischemic heart disease in middleaged British men. Br Heart J 66 : 384-394

6. Paffenbarger RS, Hyde RT, Wing AL, Lee IM, Jung DL \& Kampert JB (1993）： The association of changes in physical activity level and other lifestyle characteristics with mortality among men. N Engl J Med 328: 538-545

7 . Blair SN, Kohl III HW, Paffenbarger RS, Clark DG, Cooper KH \& Gibbons LW (1989) : Physical fitness and all-cause mortality : A prospective study of healthy men and women. JAMA 262: $2395-2401$

8. Vena JE, Graham S, Zielezny M, Swanson MK, Barnes BE \& Nolan J (1985) : Lifetime occupational exercise and colon cancer. Am J Epidemiol 122 : 357-365

9 . Sandvic L, Erikssen J, Thaulow E, Erikssen G, Mundal R \& Rodahl K (1993) : Physical fitness as a predictor of mortality among healthy, middle-aged Norwegian men. N Engl J Med 328 : 533537

10. Danneberg AL, Keller JB, Wilson PW \& Castelli WP (1989) : Leisure-time physical activity in the Framingham Offspring Study. Description, seasonal variation, and risk factor correlates. Am J Epidemiol 129: 76-78

11. Eaton CB (1992) : Relation of physical activity and cardiovascular fitness to coronary heart disease. Part I : a meta-analysis of the independent relation of physical activity and coronary heart disease. $\mathrm{J}$ Am Board Fam Pract 5: 31-42

12. Kannel WB, Wilson P \& Blair SN (1985) : Epidemiological assessment of the role of physical activity and fitness in development of cardiovascular disease. Am Heart J 109 : 876-885

13. Bloom SR, Johnson RH, Park DM, Rennie MJ \& Sulaiman WR (1976) : Differences in the metabolic and hormonal response to exercise between racing cyclists and untrained individuals. J Physiol (Lond) 258: 1-18

14. Galbo H (1983) : Hormonal and Metabolic Adaptation To Exercise. Thieme-Stratton, New York $116 \mathrm{pp}$

15. Kjer M, Bangsbo J, Lortie G \& Galbo H (1988) : Hormonal response to exercise in humans : influence of hypoxia and physical training. Am J Physiol 254: R197-R203

16. Kjer M, Christensen NJ, Sonne B, Richter EA \& Galbo H (1985) : Effect of exercise on epinephrine turnover in trained and untrained male subjects. J Appl Physiol $59: 1061-1067$

17. Dela F, Mikines KJ, von Linstow M \& Galbo H (1992) : Heart rate and plasma catecholamines during $24 \mathrm{~h}$ of everyday life in trained and untrained men. J Appl Physiol 73 : 2389-2395

18. Herbermann RB (1981) : Natural killer (NK) cells and their possible roles in resistance against disease. Clin Immunol Rev 1: 1-65

19. Pedersen BK (1985) : Natural killer cells in relation to disease. A review. Allergy 40 : 547557 
20. Nielsen H J, Pedersen BK, Moesgaard F, Haahr PM \& Kehlet H (1989) : Effect of ranitidine on postoperative suppression of natural killer cell activity and delayed hypersensitivity. Acta Chir Scand 155: $377-382$

21. Blazar BA, Rodrick ML, O’ Mahony JB, Wood J, Bessey PQ, Wilmore DW \& Mannick JA (1986) : Suppression of natural killer cell function in humans following thermal and traumatic injury. J Clin Immunol 6: 26-36

22. Klarlund K, Pedersen B K, Theander T G \& Andersen V (1987) : Depressed natural killer cell activity in acute myocardial infarction. Clin Exp Immunol 70: 209-216

23. Klokker M, Secher NH, Matzen S \& Pedersen BK (1993) : Natural killer cell activity during headup tilt-induced central hypovolemia in humans. Aviat Space Environ Med 64 : 1128-1132

24. Kappel M, Stadeager C, Tvede N, Galbo H \& Pedersen BK (1991) : Effects of in vivo hyperthermia on natural killer activity, in vitro proliferative responses and blood mononuclear cell subpopulations. Clin Exp Immunol 84 : 175-180

25. Pedersen BK (1991) : Influence of physical activity on the cellular immune system : mechanism of action. Int J Sports Med 12（Supl 1）： S23-S29

26. Bruce RA, DeRouen TA \& Hossak KF (1980) : Value of maximal exercise tests in risk assessment of primary coronary heart disease events in healthy men : Five years' experience of the Seattle heart watch study. Am J Cardiol 46: 371-378

27. Oshimi K, Gonda N, Sumiya M \& Kano S (1980) : Effects of corticosteroids on natural killer cell activity in systemic lupus erythematous. Clin Exp Immunol $40: \quad 83-88$

28. Galbo H, Richter EA, Holst JJ \& Christensen NJ (1977) : Diminished hormonal responses to exercise in trained rats. J Appl Physiol 43 : 953-958

29. Winder WW, Beattie MA \& Holman RT (1982）： Endurance training attenuates stress hormone responses to exercise in fasted rats. Am J Physiol 243: R179-R184

30. Furlan R, Piazza S, Dell' Orto S, Gentile E, Cerutti S, Pagani M \& Malliani A (1993) : Early and late effects of exercise and athletic training on neural mechanisms controlling heart rate. Cardiovasc Res 27: $482-488$

31. Brahmi Z, Thomas JE, Park M, Park M \& Dowdeswell IRG (1985) : The effect of acute exercise on natural killer-cell activity of trained and sedentary human subjects. J Clin Immunol $5: 321-$ 328

32. Pedersen BK, Tvede N, Hansen FR et al (1988) : Modulation of natural killer cell activity in peripheral blood by physical exercise. Scand J Immunol 27 : 673-678

33. Nieman DC, Nehlsen-Cannarella SL, Markoff PA, Balk-Lamberton AJ, Yang H, Chritton DB, Lee JW \& Arabatzis K (1990) : The effects of moderate exercise training on natural killer cells and acute upper respiratory tract infections. Int J Sports Med 11: 467-473

34. Kappel M, Tvede N, Galbo H, Haahr PM, Kjaer M, Linstow M, Klarlund K \& Pedersen BK (1991) : Evidence that the effect of physical exercise on NK cell activity is mediated by epinephrine. J Appl Physiol 70: 2530-2534 
運動トレーニングは安静時血中カテコーラミンとnatural killer細胞活性を 増加させる

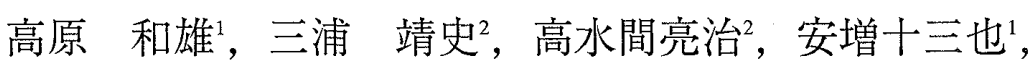
中村 正, 中島 康秀 ${ }^{2}$

産業医科大学産業保健学部 第一生体情報学教室

产業医科大学医学部 第二内科学教室

要＼cjkstart旨：運動トレーニングによるfitness, 安静時血中カテコーラミン濃度およびnatural killer 細胞活性への影響を検討した，対象は特にスポーツ活動のない健康若年女性 $(20-22$ 歳）16名である。トレーニングプロトコールとして, 最大酸素揕取量 $50 \%$ 相当の運 動強度でトレッドミルによるジョギングを 1 日 2 時間, 週 3 回10週間行った。最大 酸素摄取量は 10 週間の運動により $33.1 \pm 3.4 \mathrm{ml} / \mathrm{kg} / \mathrm{min}$ から $38.3 \pm 6.6 \mathrm{ml} / \mathrm{kg} / \mathrm{min}$ へ有意 に増加し $(P<0.005)$, natural killer細胞活性は $31.9 \pm 14.3 \%$ 加 $46.4 \pm 18.4 \%$ へ有意に 增加した $(P<0.05)$. トレーニング前後の安静時epinephrineとnorepinephrineはそれ ぞれ $18.3 \pm 8.7 \mathrm{pg} / \mathrm{ml}$ と20.4 $\pm 8.9 \mathrm{pg} / \mathrm{ml}, 134.1 \pm 52.2 \mathrm{pg} / \mathrm{ml}$ と248.1 $\pm 106.8 \mathrm{pg} / \mathrm{ml} \quad(P<$ 0.005）だった。 norepinephrine増加量とepinephrine増加量はそれぞれ最大酸素摂取量 増加量と正相関があった $(\mathrm{r}=0.780, P<0.005 ; \mathrm{r}=0.556, P<0.05)$. またnatural killer 細胞活性增加量と epinephrine増加量は正相関があった $(\mathrm{r}=0.623, P<0.01)$. これら の事より我々は若年女性において運動トレーニングは安静時血中カテコーラミンと natural killer細胞活性を增加させると結椧した。

J UOEH（産業医大誌）21（4）:277-287（1999） 